\title{
INFLUENCE OF BIO-PREPARATION ON WASTEWATER PURIFICATION PROCESS IN CONSTRUCTED WETLANDS
}

\author{
Monika Puchlik' ${ }^{1}$ Katarzyna Ignatowicz ${ }^{1}$, Wojciech Dąbrowski ${ }^{1}$ \\ 1 Białystok University of Technology, 45A Wiejska Str., 15-351 Białystok, Poland; e-mail: m.puchlik@pb.edu.pl; \\ k.ignatowicz@pb.edu.pl; dabrow@pbbialystok.pl
}

Received: 2014.09.01

Accepted: 2014.10.17

Published: 2015.01.02

\begin{abstract}
Technological system of analyzed wastewater treatment plant is in part a biological bed of soil-reed in parallel arrangement. Unusual application is the application of two independent purification lines where in the second line, a bio-preparation is additionally dosed. The constructed wetland provides high removal of organic compounds expressed as $\mathrm{BOD}_{5}$ and $\mathrm{COD}$, as well as reducing the concentration of ammonia nitrogen and phosphates. This indicates a high performance of such a sewage treatment plant.
\end{abstract}

Keywords: constructed wetland, bio-preparation, wastewater.

\section{INTRODUCTION}

In rural areas and areas with dispersed buildings, the issue of wastewater management is still unresolved. Many years of negligence in the construction of sewers and sewage treatment plants cause that many residents of rural areas are forced to solve the problem of sewage treatment individually. Only $63.6 \%$ of inhabitants used the wastewater treatment plant in the Podlaskie province in 2013 (CSO). The use of house sewage treatment plants in Podlaskie province is becoming an increasingly common method of wastewater management, wherever it is not possible to connect the sewerage network. The constructed wetland method of wastewater treatment is a process taking place with the participation of heterotrophic microorganisms as well as aquatic plants and hydrophytes existing in purposely designed objects, i.e. groundwater beds or ponds.

Constructed wetlands have the ability to accumulate and retain organic substances. The accumulation of these substances is the result of excess of the primary production in relation to the respiration of heterotrophic microorganisms active in the wetland system [www.ekologia24. biz25.05.2014, Ozimek et al. 1996]. Organic matter produced in the environment of wetland ecosystem is seasonally accumulated on the substrate surface, and then converted during microbiological processes into hard-degradable organic substances, such as humic compounds forming a new soil layer [Obarska-Pempkowiak et al. 2010, Obarska Pempkowiak 2002, Henze et al. 2000].

Bio-preparations are selected microorganisms, mainly bacteria, fungi, and enzymes, bound to the mineral medium, used for the biodegradation of organic pollutants. They are non-toxic to humans, animals and plants. Selection of bacterial cultures in bio-preparations is made in such a way to eliminate disease-forming pathogens. The purpose of the bio-preparations application is faster decomposition of organic pollutants in wastewater (manure, paper, plant debris, grease), better biodegradation of detergents and cleaners, as well as the elimination of unpleasant odors.

Along with the use of bio-preparations, part of impurities forms sediment or is permanently bound to the ground, while the rest leaves the bed with the outflow of purified wastewater. As a result, conditions that allow for development of heterotrophic microorganisms involved in the biochemical processes in the supplied sewage, are created. [Reddy, D'Angelo 1996, www.ekologia24.biz25.05.2014]. 


\section{MATERIAL AND METHODS}

The study was conducted in a household sewage treatment plant with constructed wetland bed in Dzierniakowo in Podlaskie province. The object is intended for use by 10 people. Thus, it is designed for the average wastewater flow of 1.2 $\mathrm{m}^{3} / \mathrm{d}$. Exploitation of the household sewage treatment plant with constructed wetland started in January 2012. To determine the effect of the biopreparation on the efficiency of wastewater treatment, the plant operates in parallel system and is made up of two lines operating independently of each other [Markowski 2011]. Wastewater is pre-purified in septic tanks. Wastewater from the main septic tank (1) of a volume of $2.3 \mathrm{~m}^{3}$ is separated by the well (2) evenly into two subsequent settlers of $1.5 \mathrm{~m}^{3}$ volume working in parallel, from which they are delivered to two pumping stations (P4, L4) through two independent lines. Wastewater from the pumping section flows to the wetland beds. Two identical beds (working in parallel) with a square base $4 \times 4 \mathrm{~m}$ and the bed height of $90 \mathrm{~cm}$ each. The ground-plant beds are piled in three layers: bottom layer (gravel 2-16 $\mathrm{mm}$, thickness $20 \mathrm{~cm}$ ), middle layer (sand $0.5-2$ $\mathrm{mm}, 55 \mathrm{~cm}$ ), upper layer of drainage (gravel 8-16 mm), on which common reed (Phragmites communis), was planted. A block diagram of a sewage treatment plant is shown in Figure 1.

The research has been conducted since January 2012. In this paper, the average test results from 2013, when bed was exhausted and plants acclimatized, are presented. During the whole period of research, bio-preparation BIOSAN KZ 2000 was dosed into the septic tank of the II line every 14 days. The bio-preparation includes starting conditioner along with properly assembled set of non-pathogenic microorganisms of strictly directed action resulting in decomposition and degradation of harmful substances such as: ammonia, nitrites, hydrogen sulfide, indole, skatole, mercaptans, phosphorus compounds, and other single and multi-carbonaceous organic compounds. Microbial composite has the ability to bind heavy metals, directing the desired fermentation processes, changing $\mathrm{pH}$ of the sewage and liquid manure, and very strong inhibition of pathogenic microorganisms growth, as well as enzymatic destruction of eggs and spores of insects and endoparasites [www.ekologia24.biz25.05.2014]. Biopreparation BIOSAN KZ 2000 is designed to microbial wastewater treatment of sewage in treat-

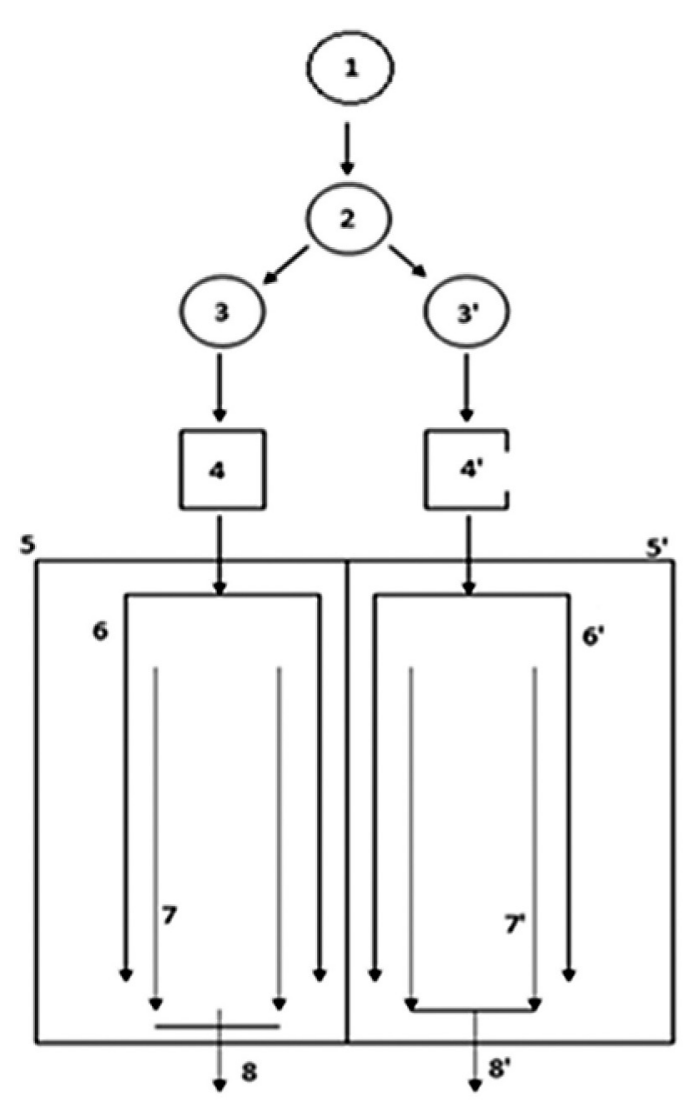

Figure 1. Scheme of constructed wetland plant: 1 septic tank, 2 - separating well, P3 - septic settler right line, L3 - septic settler - left line, P4 - sewage pumping section - right line, L4 - sewage pumping section - left line, P5 - ground-plant bed - right line, L5 - ground-plant bed - left line

ment plants, lagoons, septic tanks, liquid manure and slurry reservoirs, microbiological treatment of sewage and impurities in other facilities and devices of similar nuisances and loads, as well as elimination of unpleasant odors and microbial contamination in the environment of such objects and to improve the physicochemical and hygienic parameters of contaminated reservoirs and water intakes [www.ekologia24.biz25.05.2014]. The bio-preparation is used in an amount of $20 \mathrm{~g}$ per 1 $\mathrm{m}^{3}$ of wastewater or projected liquid waste every 14 days [www.ekologia24.biz25.05.2014].

The second line of sewage treatment plant worked independently without the addition of supporting preparations, as a control object. In order to assess the impact of bio-preparation on the efficiency of wastewater purification from both lines, samples were collected from: the septic tank before the sewage separation (1), septic tanks after the separator (2), and the outflow from constructed wetlands (3). Following items were determined in the wastewater samples in accor- 
dance with the applicable methodology: COD, $\mathrm{BOD}_{5}$, phosphates $\left(\mathrm{PO}_{4}{ }^{3-}\right)$, total phosphorus $\left(\mathrm{P}_{\text {tot. }}\right)$, ammonium nitrogen $\left(\mathrm{NH}_{4}^{+}\right)$, and Kjeldahl nitrogen (TKN).

\section{RESULTS AND DISCUSSION}

The $\mathrm{COD}$ to $\mathrm{BOD}_{5}$ ratio for raw sewage is less than 2 , which indicates that those wastewaters are readily biodegradable. The average purification effect on the bed for $\mathrm{BOD}_{5}$ was $79.2 \%$ in the left line, while $96.2 \%$ in the right line with the addition of bio-preparation; the total effect in the left line amounted to $84.3 \%$ and $97.4 \%$ in the right line (Figure 2).

The high percentage of the purification effect for $\mathrm{BOD}_{5}$ and $\mathrm{COD}$ provides the correct course of wastewater treatment from organic impurities, and achieved values at the outlet into the receiver comply with the requirements of 24 July 2006 (as amended in 2009), set by the Regulation of the Minister of Environment on the conditions to be met when discharging sewage into waters or soils, and on substances particularly harmful to the aquatic environment.

The tested sewage subjected to the treatment had $\mathrm{pH}=6.5 \div 8$, and therefore ammonia is present practically in 95 to $100 \%$ in an ionized form of $\mathrm{NH}_{4}^{+}$. Municipal sewage contains biologically non-decomposable organic nitrogen in the amount of about $2 \mathrm{mg} \mathrm{N} / \mathrm{m}^{3}$. It remains in this form and concentration in treated wastewater [Kalinowska et al. 2005]. A similar amount of organic nitrogen was observed in the test samples, which was calculated on the basis of the difference between the concentration of TKN and $\mathrm{N}_{-} \mathrm{NH}_{4}$. Organic nitrogen compounds undergo a process of ammonification already during the inflow to the sewage

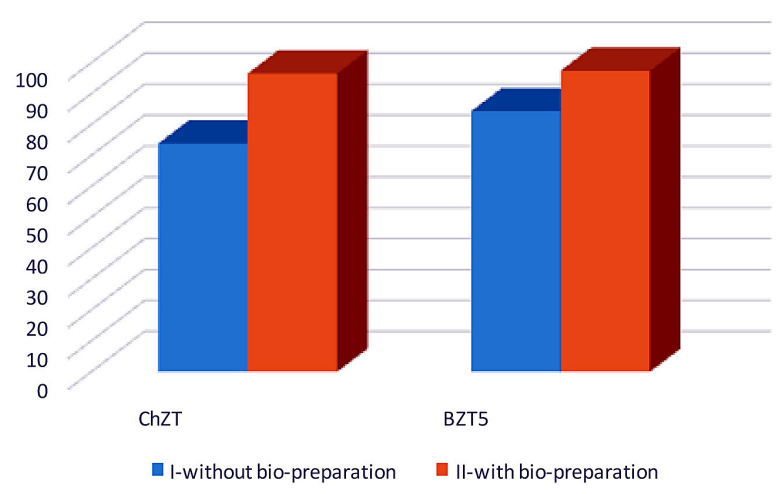

Figure 2. Efficiency of total COD and BOD [\%] in Dzierniakowo in 2013 treatment plant. As a result, the average amount of ammonia nitrogen in samples from the septic tank was $102 \mathrm{mg} \mathrm{N} / \mathrm{dm}^{3}$, and the Kjeldahl nitrogen $115 \mathrm{mg} \mathrm{N} / \mathrm{dm}^{3}$. Favorable conditions for nitrification (good oxygenation of sewage, $\mathrm{pH}$ close to 7) during the flow of wastewater through the constructed wetland contributed to the removal of ammonia nitrogen in the left line in $81.6 \%$ and in the right line with use of the bio-preparation - in $97.1 \% 9$ (Figure 3). Due to the microorganisms that can assimilate nitrogen only in the inorganic form, and for which ammonia is easily absorbed form, the concentration of $\mathrm{NH}_{4}^{+}$in the effluent flowing out to the receiver was in the left line $18 \mathrm{mg} \mathrm{N} / \mathrm{dm}^{3}$ and in the right line $2.4 \mathrm{mg} \mathrm{N} /$ $\mathrm{dm}^{3}$ (Table 1).

Mean values of the Kjeldahl nitrogen concentration in the treated wastewater is for the left line $19 \mathrm{mg} \mathrm{N} / \mathrm{dm}^{3}$, while for the right line with applied bio-preparation, a decrease to $5.3 \mathrm{mg} \mathrm{N} / \mathrm{dm}^{3}$ was recorded. This indicates the presence of a small amount of nitrogen in organic form and ammonia nitrogen that was not subject to nitrification. The activity of Nitrosomonas and Nitrobacter bacteria is provided not only by reduction in the amount of ammonia nitrogen in the outflowing sewage, but also an increase in nitrate concentration at the measurement point (after beds). Comparing the achieved values and taking into account the fact that heterotrophic bacteria in the struggle for substrates displace nitrifying bacteria, it can be assumed that a significant portion of organic load was removed on the hydrophilic bed.

A small amount of wastewater flowing into the sewage treatment plant daily makes a considerable concentration of certain pollutants. This is evident in the case of phosphates in the studied wastewater. Phosphates in wastewater have their origin mainly from synthetic detergents, wash-

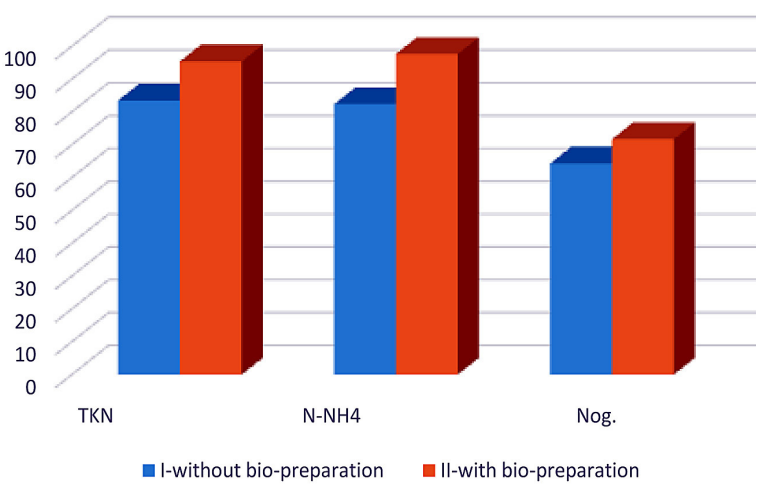

Figure 3. The effectiveness of the total forms of nitrogen [\%] in Dzierniakowo in 2013 
ing agents, and their quantity affects the total phosphorus level. In the studied raw sewage, the average phosphate concentration was $39 \mathrm{mg} \mathrm{P} /$ $\mathrm{dm}^{3}$. During the flow of wastewater through the constructed wetland, the phosphate concentration decreased to $26 \mathrm{mg} \mathrm{P} / \mathrm{dm}^{3}$ in the left line, whereas up to $10 \mathrm{mg} \mathrm{P} / \mathrm{dm}^{3}$ in the line where bio-preparation was applied. Complete effect of phosphate removing from wastewater during the study period reached $33.3 \%$ in the left, while $74.3 \%$ in the right line. Effect of the removal of total phosphorus in left line was $35.7 \%$, and $71.4 \%$ when bio-preparation was used (Figure 4). In none of tested samples, there was any increase in the phosphate concentration. No secondary release of phosphorus compounds by bacteria testifies maintaining the aerobic conditions during the wastewater treatment on the bed. Some of the phosphorus compounds were assimilated by bacteria and plants, expanding root system of which provides an environment rich in aerobic and anaerobic bacteria.

According to Sadecka and Myszograj [Myszograj 2011, Sadecka 2008], in the case of sewage from rural areas, one should be prepared to determine pollutants concentrations, other than

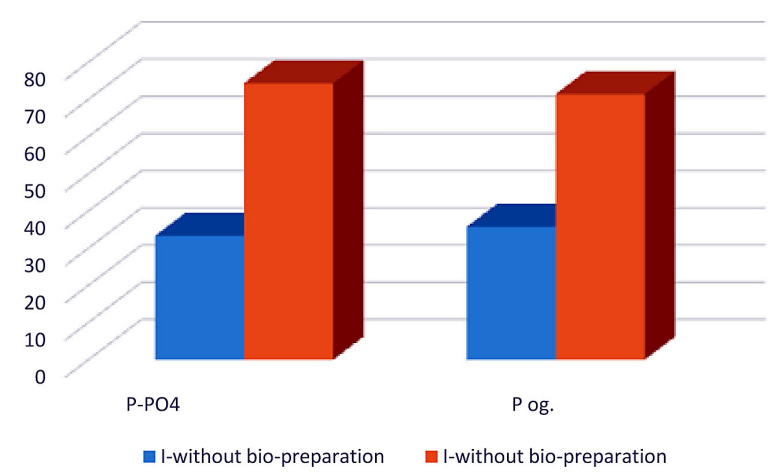

Figure 4. The effectiveness of the total phosphorus forms [\%] in Dzierniakowo in 2013 the literature, particularly in relation to the content of biogenic compounds. For the analysis of the wastewater composition, it should be remembered that they are constantly changing, what is caused by a high non-uniformity resulting from the operation cycles or habits of the people using a given treatment plant.

\section{CONCLUSIONS}

The analysis of performed measurements and calculation allows for drawing the following conclusions:

1. The use of bio-preparation Biosan KZ 2000 contributes to the increase in the efficiency of treated wastewater in household sewage treatment plants with constructed wetland.

2. Improved total efficiency of organic compounds removal expressed as COD by $22.65 \%$ and $\mathrm{BOD}_{5}$ by $13.12 \%$ with the application of bio-preparation Biosan KZ 2000, was observed.

3. The bio-preparation slightly affects the enhanced removal of total nitrogen $(7.40 \%)$ and ammonia nitrogen (15.30\%).

4. Efficiency of organic compounds removal in the constructed wetland for the line supported by the bio-preparation is higher by $23.72 \%$ for COD and by $16.99 \%$ for $\mathrm{BOD}_{5}$.

5. Removal of nitrogen forms for the bio-preparation supported line in the constructed wetland is higher by $15.43 \%$ for ammonia nitrogen and by $6.39 \%$ for total nitrogen.

6. Twice as effective phosphorus removal was observed on the bed supported by bio-preparation Biosan KZ 2000 during the whole study period.

7. Applied bio-preparation Biosan KZ 2000 clearly improves the quality of treated wastewater.

Table 1. Parameters of wastewater during the treatment process in household sewage ground-plant bed

\begin{tabular}{|c|c|c|c|c|c|c|c|c|c|c|c|c|c|c|c|c|}
\hline Sample Factor & \multicolumn{2}{|c|}{$\begin{array}{c}\mathrm{BOD} \\
\mathrm{mg} \mathrm{O}_{2} / \mathrm{dm}^{3}\end{array}$} & \multicolumn{2}{|c|}{$\begin{array}{c}\mathrm{COD} \\
\mathrm{mg} \mathrm{O}_{2} / \mathrm{dm}^{3}\end{array}$} & \multicolumn{2}{|c|}{$\begin{array}{c}\text { TKN } \\
\mathrm{mg} \mathrm{N} / \mathrm{dm}^{3}\end{array}$} & \multicolumn{2}{|c|}{$\begin{array}{c}\mathrm{N}-\mathrm{NH}_{4}^{+} \\
\mathrm{mg} \mathrm{N} / \mathrm{dm}^{3}\end{array}$} & \multicolumn{2}{|c|}{$\begin{array}{c}{\mathrm{N}-\mathrm{NO}^{-}}^{-} \\
\mathrm{mg} \mathrm{N} / \mathrm{dm}^{3}\end{array}$} & \multicolumn{2}{|c|}{$\begin{array}{c}\text { Nog. } \\
\mathrm{mg} \mathrm{N} / \mathrm{dm}^{3}\end{array}$} & \multicolumn{2}{|c|}{$\begin{array}{c}\text { Pog. } \\
\mathrm{mg} P / \mathrm{dm}^{3}\end{array}$} & \multicolumn{2}{|c|}{$\begin{array}{l}\mathrm{P}-\mathrm{PO}_{4}^{3-} \\
\mathrm{mg} / \mathrm{dm}^{3}\end{array}$} \\
\hline $\begin{array}{l}\text { Separating } \\
\text { well (1) }\end{array}$ & \multicolumn{2}{|c|}{$\frac{435-520}{427}$} & \multicolumn{2}{|c|}{$\frac{642-851}{746}$} & \multicolumn{2}{|c|}{$\frac{74-165}{115}$} & \multicolumn{2}{|c|}{$\frac{65-139}{102}$} & \multicolumn{2}{|c|}{$\frac{0.1-4.4}{2.7}$} & \multicolumn{2}{|c|}{$\frac{74.1-169.4}{117.7}$} & \multicolumn{2}{|c|}{$\frac{22-65}{42}$} & \multicolumn{2}{|c|}{$\frac{20-60}{39}$} \\
\hline Series & I & $\|$ & 1 & $\|$ & 1 & $\|$ & 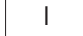 & $\|$ & I & ॥ & 1 & $\|$ & 1 & ॥ & 1 & $\|$ \\
\hline Septic settler (2) & $\frac{190-450}{323}$ & $\frac{130-400}{499}$ & $\frac{557-765}{674}$ & $\frac{251-770}{499}$ & $\frac{76-156}{102}$ & $\frac{68-117}{96}$ & $\frac{66-136}{98}$ & $\frac{58-106}{83}$ & $\frac{0.1-7.0}{4.8}$ & $\frac{0.2-5.8}{5.1}$ & $\frac{76.1-163}{106.8}$ & $\frac{68.2-122.8}{101.1}$ & $\frac{3.1-67}{43}$ & $\frac{23-58}{33}$ & $\frac{21-58}{39}$ & $\frac{19-47}{29}$ \\
\hline $\begin{array}{l}\text { Ground-plant } \\
\text { bed (3) }\end{array}$ & $\frac{27-107}{67}$ & $\frac{5.0-20}{11.0}$ & $\frac{107-235}{195}$ & $\frac{5.0-36}{26}$ & $\frac{5.0-38}{19}$ & $\frac{3.0-11.0}{5.3}$ & $\frac{3.0-37}{18}$ & $\frac{1.4-7.0}{2.4}$ & $\frac{0.5-45}{23}$ & $\frac{3.0-45}{28}$ & $\frac{5.5-83}{42}$ & $\frac{7.0-56}{33.3}$ & $\frac{6.0-37}{27}$ & $\frac{4.0-26}{12}$ & $\frac{5.0-36}{26}$ & $\frac{2.0-23}{10}$ \\
\hline
\end{tabular}

$\underline{\min -\max }$

medium 


\section{Acknowledgments}

Financial support for this research was provided by Ministry of Science and Higher Education within the project N N304 274840 and W/ WBiIŚ/8/2013.

\section{REFERENCES}

1. Obarska-Pempkowiak H., Gajewska M., Wojciechowska E. 2010. Hydrofitowe oczyszczanie wód i ścieków. Wydawnictwo Naukowe PWN 2010.

2. Ozimek T., Renman G. 1996. Rola heliofitów w oczyszczalniach hydrobotanicznych. [In:] II Międzynarodowa Konferencja Naukowo-Techniczna, Akademia Rolnicza w Poznaniu, Poznań, 109-118.

3. http://www.ekologia24.biz/oczyszczalnie/biopreparat-biosan-kz-2000-25.05.2014r.

4. Obarska-Pempkowiak H. 2002. Oczyszczalnie hydrofitowe. Wydawnictwo Politechniki Gdańskiej, Gdańsk.

5. Reddy K.R., D’Angelo E.M. 1996. Biochemical indicator to evaluate pollutant removal efficiency in constructed wetland. [In:] 5th International Conference on Wetland Systems for Water Pollution Control. Universität für Bodenkultur Wien and International Association on Water Quality. Vienna.

6. Markowski W. 2011. Wpływ biopreparatów na efektywność usuwania związków węgla w przydomowej oczyszczalni ścieków ze złożem hydrofitowym. Praca magisterska. Politechnika Białostocka, 76-86.

7. Kalinowska E., Bonar G., Duma J. 2005. Zasady i praktyka oczyszczania ścieków. Wyd. LEMTECH Konsulting, Kraków.

8. Henze M., Harremoes P., Jansen J., Arvin E. 2000. Oczyszczanie ścieków. Procesy biologiczne i chemiczne. Wyd. Politechniki Śląskiej, Kielce.

9. Myszograj S. 2008. Zmiany ilościowe i jakościowe ścieków dopływających do małych oczyszczalni. [In:] Oczyszczanie ścieków i przeróbka osadów ściekowych, Tom 2, Zielona Góra.

10. Sądecka Z. 2008. Oczyszczanie ścieków z małych miejscowości. [In:] Oczyszczanie ścieków i przeróbka osadów ściekowych, Tom 2, Zielona Góra. 